\title{
THE LONELINESS OF THE LIBRARIAN
}

\section{Veronica Brady}

\author{
University of Western Australia
}

Sister Veronica Brady, a member of the Loretto Order, has taught for many years in the Department of English at the University of W.A. specialising in Australian Literature. Having retired in 1994 she is now a Senior Research Fellow in the Department.

For many years she has

been concerned with social justice issues particularly justice for Aboriginal Australians, environmental protection and world peace. She has also been a member of various boards from the Australian Broad c a sting Corporation to the Appeals Tribunal of the Department of Social Security.

Her books include "Caught in the Draught" and "Can These Bones Live?"

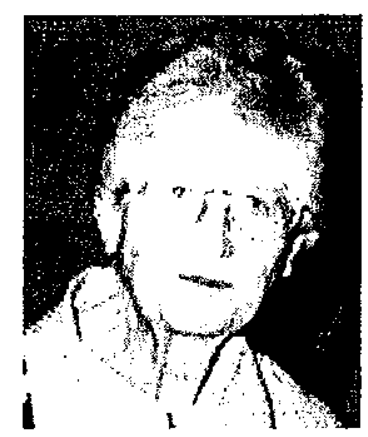

The title of this paper in your program is 'The Lure? Lore of the Library'. However, on reflection, I have changed it to 'The Loneliness of the Librarian'. My next move-a pause to remember that we are on Noongah land and to honour the people who have lived here and cared for it for thousands of years-may suggest why my new topic might be to the point.

Recently I came across a reference to a paper by Rav Joseph Soloveitchik, 'The Lonely Man of Faith' ${ }^{1}$ and I suspect, even hope perhaps, that it may apply to you as librarians, especially perhaps as librarians who work in theological libraries. Let me explain.

I do not want to assume that you yourselves are theologians or belong to the church groups you serve. But I hope I can assume that you believe in your profession and its commitment to the fundamentals of what we call the humanities, fundamentals which to my mind have much to do with the concerns of theology. That belief, I suggest, may-perhaps should-set you at odds with a world in which libraries are increasingly at the service of information or, with luck, of knowledge, but has little to do with wisdom. (I will spend some time later in reflecting on the difference between them.)

I presume therefore that, as Soloveitchik says, if you are not to be too lonely you need to be sustained by a community of friends which is not a matter of the social surface but existential in depth, based on a shared sense of reality and value. 'Understaffed, under-funded and often misunderstood' as you may be, this sharing may be one of the fruits of your coming together here.

This emphasis on loneliness may sound negative. But be of good heart, margins can be good and creative places: it is often 'from the deserts that the prophets come' or, to put it in less exalted language, those who think outside the circle often think most incisively and powerfully. Consider, for example, Wittgenstein's insight:

'The general form of propositions is: This is how things are.' That is the kind of proposition that one repeats to oneself countless times. One thinks that one is tracing the outline of the thing's nature over and over again, and one is merely tracing round the frame through which we look at it.

A picture held us captive. And we could not get outside it for it lay in our language and our language seemed to repeat it to us inexorably. ${ }^{2}$ 
So let us set aside the language of our culture and of the courses, professional journals and culture which may be part of this répetition, take the frame off, and see what emerges.

To begin with let us reflect on the meaning of the word 'library'. As you know, it has to do with books-the root meaning of the word comes from the Latin for 'book'and it is a word with a wonderful history. Consider, for example, the resonance of 'the book', as applied to the Bible or the phrase 'the book of nature' or sayings like 'bring to book', a 'closed book' or being in someone's 'good books'. The conclusion of St John's Gospel even suggests God's high regards for books, telling us that 'if everything Jesus did were written down, ... the world itself could not contain the books that would be written'.

It is true that this might seem sadly oldfashioned. There is much talk, today of the 'death of the book' and an increasing amount of your professional time is taken up with computers, information systems and so on and so forth. But that brings us to the distinction between information, knowledge and wisdom, a distinction I would like to reflect on not to be pedantic but because 1 think the crucial issue people in your profession face is not so much the means you use-whether it be books, leaves of paper bound together covered with black marks or computers, machines usually shaped like a kind of box with a television-like screen displaying black marks similar in kind to those in books, figures diagrams and so on-but the end we hope to serve .

As things are today, by and large the goal of many if not most libraries is to provide information, give access to facts, figures, trends and so on within the present order of things. Computers do this very well, perhaps better than books.

Knowledge comes next, and it may be that books are just as effective, if less fast in their delivery here, though if you define 'knowledge' as understanding of general truths or principles, general erudition about the world and human behaviour, it may be a cumulative rather than instantaneous affair. As you know only too well most clients of libraries want what they want as quickly as possible, so you must bow to their needs. But in the libraries in which you work, I suggest you are professionaliy privileged, since the goal of theology is not mere information or knowledge but wisdom, something quite different, threatened perhaps in the kind of world we inhabit.

Its etymology suggests why this is so. The word wisdom derives from two AngloSaxon words, wys, the equivalent of the Greek word arete, the perfection of a thing or quality, and the suffix dom which has to do with dwelling, with some abiding state. So it implies an awareness of reality in the deepest sense, a kind of dwelling or being at home in a cosmic sense, in things as they ultimately are. Scripture sees wisdom as a maternal presence, caring for creation and showing us how to be at home in it. Evidently the kind of knowledge theology is about is of this kind, and that is why you may feel lonely at times.

That is not to say that you will not use computers but, as I have said, your goal is different and involves a different kind of reading since it is concerned with a different kind of knowing, the kind associated with reading books, in particular the kind of books which have a certain magical quality about them since they attempt to create new kinds of experience, knowledge or insight, setting us free from the trammels of the way things actually are to open up a world of possibility. As Sir Philip Sidney wrote in his Apology For Poetry this is knowledge of a special kind. All others have the works of nature as their principal object but

only the poet [by which he means the creative writer or thinker], disdaining to be tied to any such subjection, lifted up with the vigour of his own invention, doth grow in effect another nature, in making things either better than nature bringeth forth, or quite anew. ${ }^{3}$ 
Literature does this but so does philosophy and, most especially perhaps, theology since it is attempting to speak about what is ultimately unspeakable, the realm of what Karl Rahner calls

the "silent one" who is always there, and yet can always be overlooked, unheard, and because it expresses the whole in its unity and totality, can be passed over as meaningless. ${ }^{4}$

What you are enabling therefore is an activity which goes against the grain of our culture and can be dismissed as useless or merely idealistic. But contemporary history tells us how dangerous those who attach the word 'mere' to idealism can be and the frightening nature of a culture prepared to agree with them.

Heinrich Blucher, German and Jewish, who escaped from Hitler's Germany and later married Hannah Arendt, knew this :

The random undercurrent of human events [today] is a maelstrom, driven by interests that suck us down into the depths. For an interest is not the cunning of reason but the obfuscation of reason. This societal maelstrom has smashed into European history and flooded it ... [creating a] boiling mass of ghostlike, isolated individuals ... [who] want to move directly from the past to the future by leaping over the present, as if a future could ever open up for human beings who have lost sight of eternity. ${ }^{5}$

In this world human beings seem increasingly superfluous, not even means to an end but simply not part of an equation which is based mechanically on calculations of economic profit and technical efficiency. The search for understanding and meaning, belief and beauty, give way to these imperatives and community becomes a matter of 'the weird irreality of closely packed human beings', and indifference to and sometimes even vengeance towards others and the rest of creation, a way of life.

As a teacher for most of my life, I am convinced that librarians also have a teaching role, keeping alive the kind of reading which leads to wisdom and is therefore counter-cultural since it is essentially active rather than passive, a reading which involves a rewriting, challenges the ego asking it not only to think but to imagine also and thus to think more deeply about accepted notions of reality and value and in this way to come to the self-knowledge that results from self-interrogation and releases us from the tyranny of the known, which refuses to respect the unknown.

Milton argued for this in his passionate defence of freedom of expression, the Areopagitica writing that

the light which we have gained was given us, not to be ever staring on, but by it to discover onward things more remote from our knowledge. ${ }^{6}$

In this sense truth is not a matter of dogmatism but openness to revelation and steadfastness and patience in its pursuit.

You need, too, to defend tradition, the contract between those who are living, those who are dead and those who are yet to be born, as Edmund Burke described it and thus keep memory alive and with it the sense of eternity so lacking in the culture of instant satisfaction and constant titillation.

Archives are crucial, even if archivists are sometimes the loneliest people in your profession. Theologicaliy, too, it is crucial to keep memory alive, in this country especially, since the forgotten dead, those already vanquished or forgotten, like so many Aboriginal people and nameless pioneers defeated by circumstance, have a meaning as yet unrealised in the struggle for justice, understanding and forgiveness.

\section{To conclude}

What I have been saying may make you feel lonely. But in a culture 'distracted by distraction from distraction' it may be important to ask the large questions and take a long view. Let me leave you then first of all with Milton's vision of the library as a powerhouse of thought, 
the mansion house of liberty ... ; the shop of war hath not there more anvils and hammers waking, to fashion out the plates and instruments of armed justice in defence of beleaguered truth, than there be pens and heads there; sitting by their studious lamps, musing, searching, revolving new notions and ideas wherewith to present ... the coming reformation. ${ }^{7}$

And if that seems too energetic, I offer you Yeats in praise of contemplation, reading's apogee, the first stanza of 'Long-Legged Fly' :

That civilisation may not sink, Its great battle lost,

Quiet the dog, tether the pony

To a distant post :

Our master Caesar is in the tent

Where the maps are spread,

His eyes fixed upon nothing,

$A$ hand under his head.

Like a long-legged fly upon the stream

His mind moves upon silence. ${ }^{8}$

Veronica Brady

University of Western Australia

\section{References}

1 Soloveitchik, quoted in Randi Rashkover "On the Loneliness of Faith", Crosscurrents 52:4 (Winter 2003), 436

2 L.Wittgenstein, Philosophical Investigations. Oxford, Blackwell, 1974, 114-115, 48e

3 P.Sidney in The Norton Anthology of English ! iterature I. NY, Norton, 1962, 426

$4 \mathrm{~K}$. Rahner, Foundations of Christian Faith. NY, Crossroad, 1985, 46

$5 \mathrm{H}$. Blucher in Correspondence of Hannah Arendt and Karl Jaspers 1926-1965. NY, Harcourt Brace, 1992, 278.

6 Milton, Areopagitica in The Norton Anthology of English Literature 1. NY, Norton, 1962, 908

$7 \mathrm{lbid}, 911$.

8 The Collected Poems of W.B. Yeats. London, Macmillan, 1971, 381.

\section{ANZTLA 2003 CONFERENCE PHOTO}

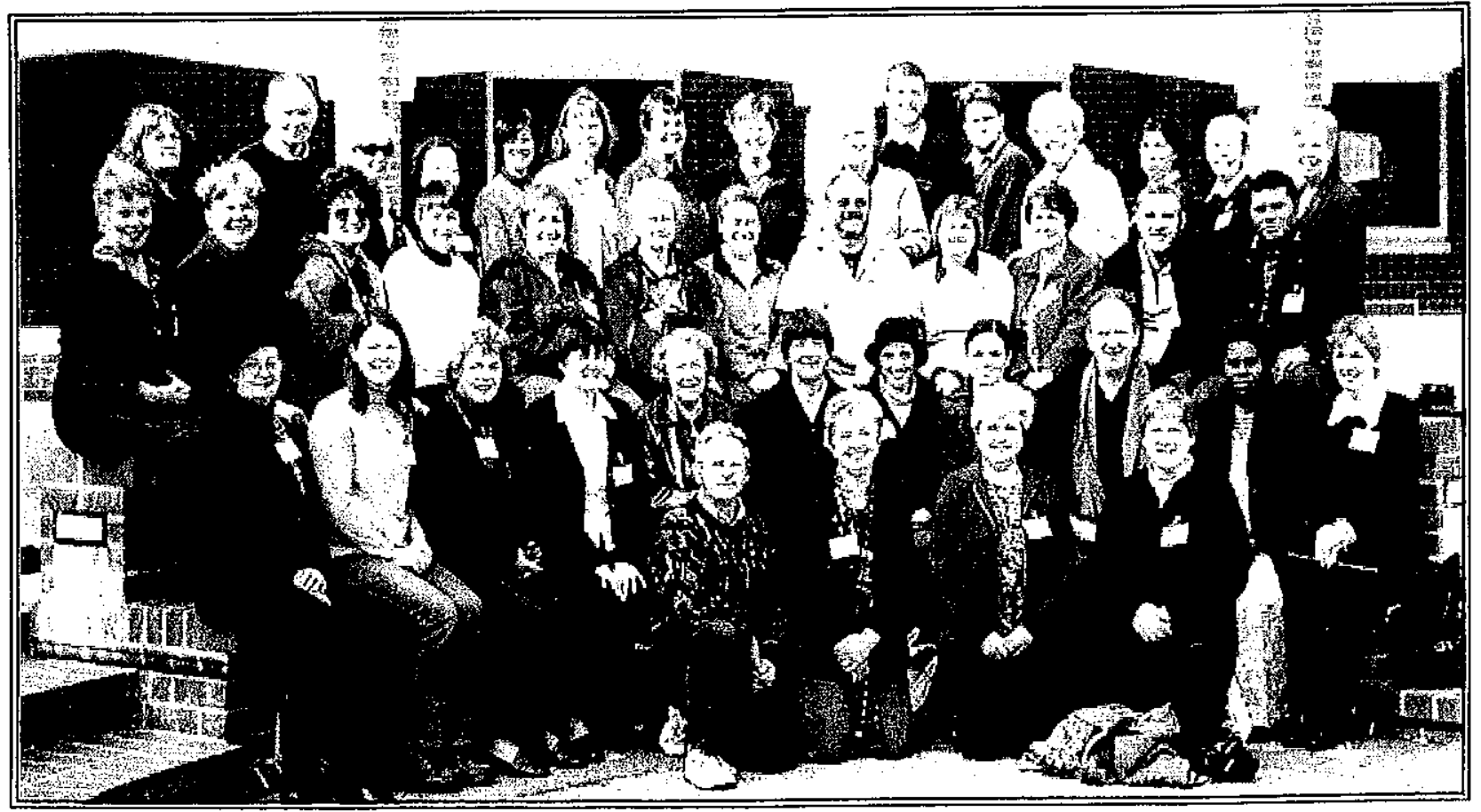

